\title{
Immobilization of $\beta$-Galactosidase in Adsorptive Membranes for the Continuous Production of Galacto-Oligosaccharides from Lactose ${ }^{\S}$
}

\author{
Larisa Engel ${ }^{1}$, Philipp Schneider ${ }^{1}$, Mehrdad Ebrahimi ${ }^{1}$ and Peter Czermak $^{*}, 1,2$ \\ ${ }^{I}$ University of Applied Sciences Giessen-Friedberg, Institute of Biopharmaceutical Technology-IBPT, Wiesenstrasse 14, \\ D-35390 Giessen, Germany \\ ${ }^{2}$ Kansas State University, Department of Chemical Engineering, 105 Durland Hall, Manhattan, KS 66506, USA
}

\begin{abstract}
A method for immobilization of $\beta$-galactosidase from Kluyveromyces lactis on an adsorptive membrane for the continuous synthesis of galacto-oligosaccharides from lactose was carried out. The immobilization was performed at 4, 10,15 and $40^{\circ} \mathrm{C}$. Two strongly basic anion exchange membranes with tradename Mustang ${ }^{\mathrm{TM}} \mathrm{Q}$ and Sartobind ${ }^{\mathrm{TM}} \mathrm{Q}$ were investigated. In static experiments, the highest enzyme activity was measured on Mustang ${ }^{\mathrm{TM}} \mathrm{Q}$ membranes at the immobilization temperature of $10^{\circ} \mathrm{C}$. The synthesis of GOS was performed in a Continuous Membrane-ChromatographyReactor-System (CMCRS) at $40^{\circ} \mathrm{C}$ and $\mathrm{pH} 7.0$ using $20 \mathrm{wt} \%$ initial lactose concentration. The investigated membranes proved to be a good support for the continuous process at high convective flow rates in the enzyme reactor system. Up to $82 \%$ lactose conversion with $24 \%$ GOS yield was achieved at different fluxes. The corresponding reactor productivity for the production of GOS from lactose in the CMCRS was 98.7 grams GOS per hour and cubic centimeter membrane volume, which significantly exceeds previously reported results.
\end{abstract}

Keywords: Immobilization, $\beta$-galactosidase, galacto-oligosaccharides, adsorptive membrane, chromatography membrane, membrane reactor.

\section{INTRODUCTION}

$\beta$-Galactosidase (EC 3.2.1.23), commonly known as lactase, catalyses not only the hydrolysis of lactose to the monosaccharides glucose and galactose but also the transgalactosylation reaction to produce galacto-oligosaccharides (GOS) [1-3].

GOS are non-digestible oligosaccharides which are recognized as prebiotics. Prebiotics have been found to reach the human colon without being hydrolyzed or absorbed in the upper part of the gastrointestinal tract. GOS selectively stimulate the growth of bifidobacteria in the lower part of the human intestine. Increase in the growth of bifidobacteria is usually accompanied by suppression of potentially harmful bacteria such as Clostridia and Bacteroides species in the intestine [1,4-7].

GOS consist of a number of oligosaccharides with varying $\beta$-glycosidic linkages depending on the enzyme source. There have been several investigations on the synthesis of GOS by $\beta$-galactosidases. Especially, $\beta$-galactosidase from Kluyveromyces lactis has been extensively studied. The enzyme was reported to have stronger hydrolytic activity than transferase activity and produced a high proportion of trisaccharides in the synthetic GOS mixtures $[1,3,8,9]$.

In food industry the widely used processes for the enzymatic catalyzed production of galacto-oligosaccharides are

\footnotetext{
*Address correspondence to this author at the University of Applied Sciences Giessen-Friedberg, Institute of Biopharmaceutical Technology-IBPT, Wiesenstrasse 14, D-35390 Giessen, Germany; Tel: 49-641-3092551; E-mail: peter.czermak@tg.fh-giessen.de

\$Partly presented at the 7th Carbohydrate Bioengineering Meeting (CBM7), 22.-25.4.2007, Braunschweig, Germany.
}

discontinuous, with enzyme in suspension, because sterile conditions and process control are easily performed.

Enzyme immobilization over a solid support is another type of process that has been developed. This technique allows a continuous process with highly pure products, but presents some disadvantages such as difficult cleaning and sterilization.

Some techniques have been developed for immobilization of $\beta$-galactosidase including non-covalent adsorption, covalent binding, entrapment and encapsulation [1-3, 10-15].

Recent improvements in membrane materials and chemistry have awoken renewed interest in applications of membrane chromatography for bioprocessing.

The chromatography membranes are an ion exchange support containing functional quaternary amines or sulphopropyl groups on a backbone of cross-linked polyethersulfone (PES) or regenerated cellulose.

The binding of enzymes on the chromatography membranes is based on the ionic interaction between the enzyme and the chromatography membrane. At a given $\mathrm{pH}$ the enzymes are mainly positively or negatively charged.

The solid chromatography membranes are carrying functional groups which are positively (anion exchanger) or negatively (cation exchanger) charged.

The charged enzyme will be adsorbed by charged membrane whereas the positively charged membrane will adsorb the enzymes with negative charge and negatively charged membrane will adsorb the enzymes with positive charge.

The membranes are porous as opposed to traditional ion exchange membranes as they are used in electrodialysis. The pores in the membranes are large enough to allow the pro- 
teins and enzymes access to all the binding sites by direct fluid convection.

As a result of the convective flow of the solution through the pores, the mass transfer resistance is tremendously reduced, and the binding kinetics dominates the adsorption process [16,17]. This results in a rapid processing, which greatly improves the adsorption, washing, elution, and regeneration steps and decreases the probability of inactivation of biomolecules.

Compared to column chromatography, which involves high pressure drops for small beads and compaction for soft gels at high flow rates, membrane chromatography has a lower pressure drop, higher flow rate and higher productivity as a result of the microporous/macroporous structure of the thin membrane $[18,19]$.

The easy packing and scale-up, as well as the unlikely fouling/clogging, provide additional advantages.

Consequently, membrane chromatography is a promising large-scale separation process for the isolation, purification, recovery of proteins and enzymes.

In our study, the membrane adsorbers have been investigated as an alternative support for immobilization of the enzyme $\beta$-galactosidase. Some of the advantages of immobilizing enzymes via physical adsorption on an activated support are: the activated support is chemically inert, good stability during storage, controlled residence time on the enzyme, simple recovery of the enzyme after usage, the possibility of a continuous process in enzyme reactors, the elimination of carryover of the enzyme to the final product $[2,12,14]$.

Our study focuses on developing a method for immobilization of $\beta$-galactosidase in a chromatography ion exchange membrane, investigating the properties of the immobilizate and the possibility of using the immobilized enzyme system for the continuous synthesis of GOS from lactose in a Continuous Membrane-Chromatography-Reactor-System (CMCRS).

The immobilization tests were performed at different temperatures. The $\beta$-galactosidase from Kluyveromyces lactis was chosen as a model enzyme for this study. Strongly basic anion exchange membranes were used here to achieve optimal conditions for the enzyme ( $\mathrm{pH}$ 6.8-7.0). Two commercial chromatography membranes made from different membrane materials were investigated.

\section{MATERIALS AND METHODS}

Deionized water was used. $50 \mathrm{millimol} / \mathrm{liter}$ potassium phosphate containing 5 millimol/liter $\mathrm{MgSO}_{4}(\mathrm{pH}$ 7.0) was used as equilibration buffer in all experiments. The lactose monohydrate was food grade (99.95\% pure, Meggle $\mathrm{GmbH}$, Wasserburg, Germany). Lactose monohydrate (for HPTLC) and other chemicals all in p.a. quality were purchased from VWR International GmbH (Darmstadt, Germany)
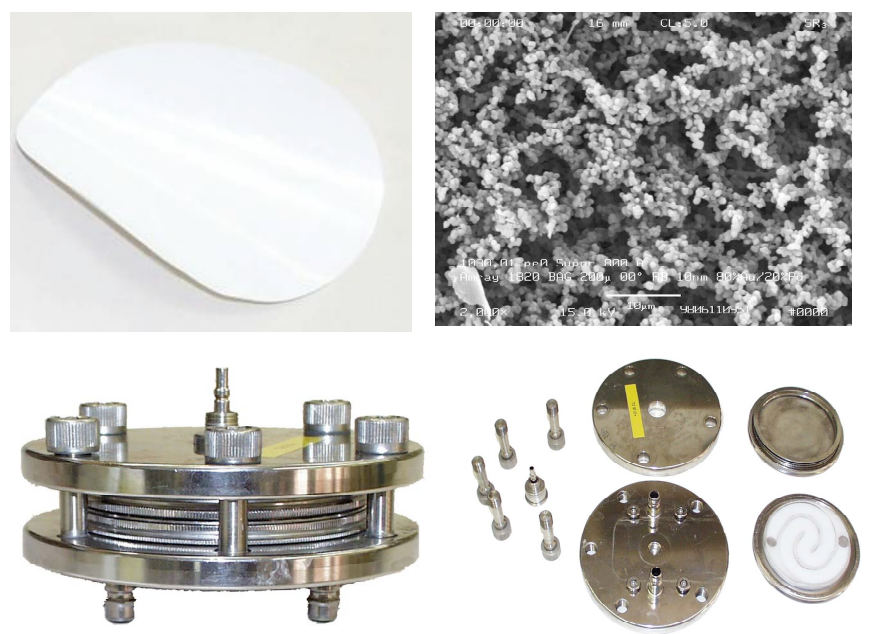

Fig. (1). Mustang ${ }^{\mathrm{TM}} \mathrm{Q}$ membrane (PES, $0,8 \mu \mathrm{m}$ ) and filter holder type TPP-90.

\section{Enzyme}

The commercial $\beta$-galactosidase from Kluyveromyces lactis (Maxilact L 2000) with a MW of about $117 \mathrm{kDa}$ and an activity of $2000 \mathrm{NLU} / \mathrm{g}$ was used in all experiments (DSM, Delft, The Netherlands). The enzyme has temperature optimum of $35-40^{\circ} \mathrm{C}$ and a $\mathrm{pH}$ optimum of $6.8-7.0$. The enzyme was used without further purification.

\section{Membranes}

The Mustang ${ }^{\mathrm{TM}} \mathrm{Q}$ membrane adsorbers (PES) obtained from Pall GmbH (Dreieich, Germany) and Sartobind ${ }^{\mathrm{TM}} \mathrm{Q}$ from Sartorius AG (Göttingen, Germany) as described in Table 1 were used as a flat sheet $(9 \mathrm{~cm}$ diameter disc) in a commercial filter holder type TPP-90 (Fig. 1), Amafilter Deutschland GmbH (Düsseldorf, Germany). The feed flow in this filter holder is directed in a spiral pattern using channels (height about $2.8 \mathrm{~mm}$ ) in the top of the filter holder (Fig. 1).

Table 1. Membrane Specifications (as Indicated by the Manufacturer)

\begin{tabular}{|c|c|c|}
\hline manufacturer & Sartorius & Pall \\
\hline trademark & Sartobind ${ }^{\mathrm{TM}} \mathrm{Q}$ & Mustang ${ }^{\mathrm{TM}} \mathrm{Q}$ \\
\hline membrane material & reinforced stabilized cellulose & supported cross-linked polyethersulfone (PES) \\
\hline \multirow{2}{*}{ functional group } & \multicolumn{2}{|c|}{ quaternary ammonium $-\mathrm{R}-\left(\mathrm{CH}_{2}\right)_{2}-\mathrm{N}^{+}-\left(\mathrm{CH}_{3}\right)_{3}$} \\
\hline & \multicolumn{2}{|c|}{ Strongly basic anion exchanger } \\
\hline bed height [mm] & 0.275 & 0.138 \\
\hline bed volume for $9 \mathrm{~cm}$ disc $\left[\mathrm{cm}^{3}\right]$ & 1.749 & 0.878 \\
\hline pore size $[\mu \mathrm{m}]$ & $>3$ & 0.8 \\
\hline binding capacity (for BSA) & $0.8 \mathrm{mg} / \mathrm{cm}^{2}$ & $60 \mathrm{mg} / \mathrm{ml}$ membrane volume \\
\hline
\end{tabular}




\section{Continuous Membrane-Chromatography-Reactor-System (CMCRS)}

The membrane was mounted in the filter holder. The feed reservoir containing substrate solution was kept on a heated magnetic stirrer to maintain the constant reaction temperature. The substrate solution in the mixed reservoir was continuously pumped through the membrane reactor with immobilized enzyme. The retentate was flushed back to the well-mixed reservoir.

\section{Immobilization of $\beta$-Galactosidase}

The immobilization procedure consisted of six main steps:

Equilibration. After placement of the membrane disc in the filter holder the system was rinsed with the equilibration buffer at $30 \mathrm{ml} / \mathrm{min}$ permeate flow.

Enzyme immobilization. Immobilizations were carried out at $40,15,10$ and $4^{\circ} \mathrm{C}$ at $\mathrm{pH} 7.0$ by pumping the enzyme solution at the permeate flow of $30 \mathrm{ml} / \mathrm{min}$ or $2.6 \mathrm{ml} / \mathrm{min}$ for $30 \mathrm{~min}$ from a well-mixed reservoir through the membrane reactor and back to the well-mixed reservoir. The enzyme solution and the whole system were cooled with ice during the immobilization as needed. Before and after immobilization the samples were taken from enzyme solution and analyzed immediately for protein concentration using the Bradford method.
Washing. After binding of the enzyme the system was washed several times with equilibration buffer $(30 \mathrm{ml} / \mathrm{min}$ permeate flow) at $40^{\circ} \mathrm{C}$ to remove non-bound enzyme. Periodically, samples of the supernatant were withdrawn and analyzed for protein concentration.

Elution. To determine the amount of the bound enzyme the system was rinsed with the elution solution containing 1 mol NaCl / liter equilibration buffer at $30 \mathrm{ml} / \mathrm{min}$ permeate flow. Periodically, samples of the supernatant were withdrawn and analyzed for protein concentration. Finally the system was flushed with the equilibration buffer.

Membrane regeneration. For removing of impurities, such as precipitated protein or other adsorbed substances the system was rinsed with the regeneration solution containing $1 \mathrm{~mol} \mathrm{NaOH} /$ liter deionized water at $30 \mathrm{ml} / \mathrm{min}$ permeate flow.

\section{Synthesis of Galacto-Oligosaccharides}

For all synthesis experiments the steps of equilibration, immobilization, washing, elution and membrane regeneration were similar to the steps described above. Continuous enzyme reactions were carried out in a thermostat water bath (GFL, Burgwedel/Germany) at $40^{\circ} \mathrm{C}$ in continuous production mode (Fig. 2). The substrate solution was prepared by dissolving lactose monohydrate $(20 \mathrm{wt} \%)$ in equilibration buffer. The reaction was followed for $1 \mathrm{~h}$ and samples were taken from filtrate every 10 minutes to analyze the composition of products.

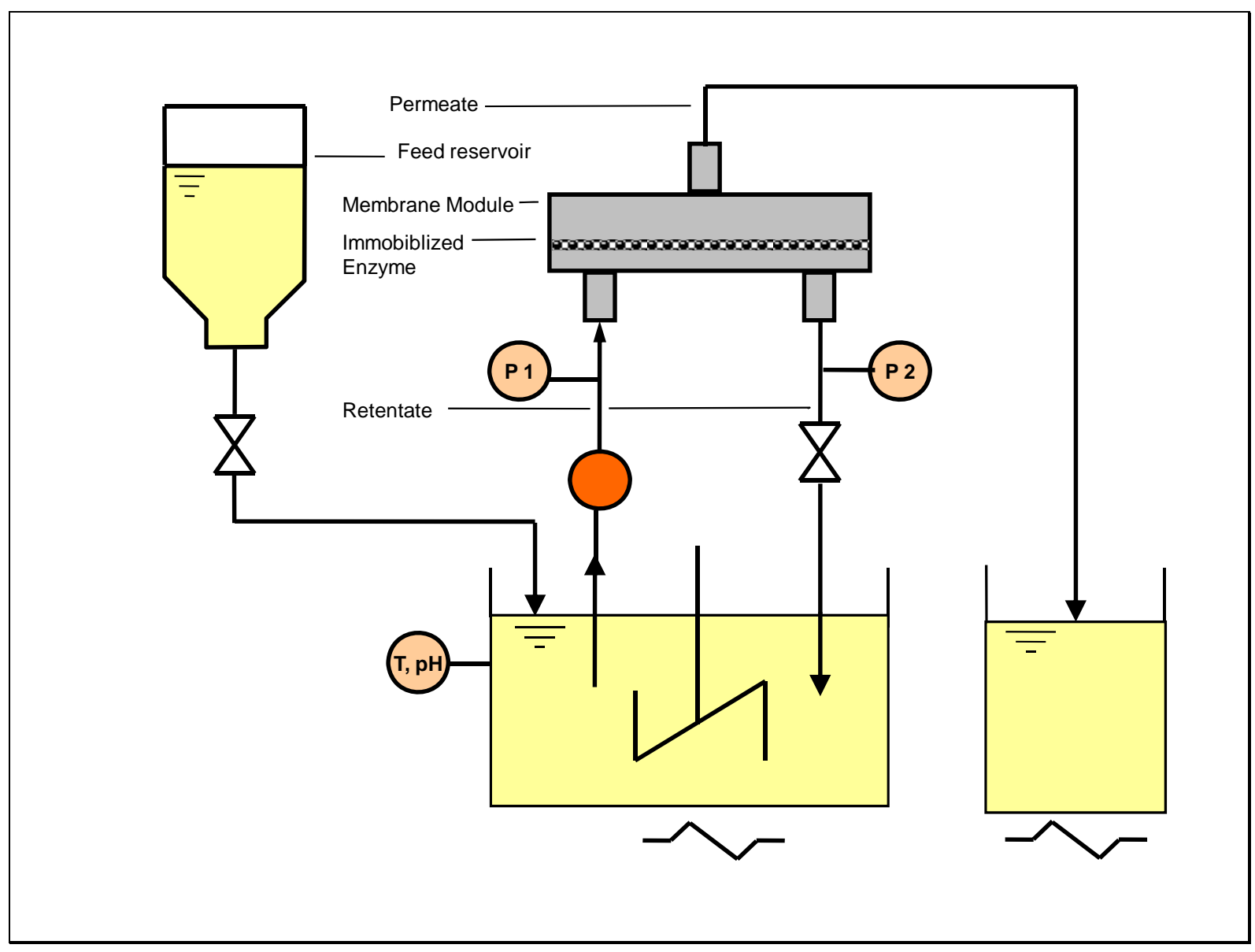

Fig. (2). Laboratory scale membrane- chromatography-reactor-system, continuous production mode. 


\section{Analytics}

\section{Protein Determination}

Protein concentration was determined by the Bradford microassay using bovine serum albumin as standard. The concentration of stock solution was $0.1 \mathrm{mg} / \mathrm{ml}$.

Average protein capture efficiency was defined by the amount of protein adsorbed on the membrane divided by the amount of protein in the original solution.

\section{Activity Determination of Immobilized Enzyme}

After washing step the membrane was removed from the filter holder and incubated for $10 \mathrm{~min}$ in $40 \mathrm{ml}$ buffered 0.1 molar lactose solution at $30^{\circ} \mathrm{C}$. The samples were taken and glucose concentration was determined with the D-Glucose Assay Kit (R-Biopharm AG, Darmstadt/Germany).

\section{Determination of $\mathrm{GOS}$}

High performance thin layer chromatography (HPTLC) was used to analyze the composition of the filtrate. The carbohydrates were separated on HPTLC Silicagel-60 plates (VWR International GmbH, Darmstadt/Germany) with double development using 1-butanol-2-propanol-water (3:12:4 [vol/vol/vol]) as the mobile phase.

Detection was achieved by dipping the plates in derivatization reagent (containing $2 \mathrm{~g}$ diphenyl-amine, $2 \mathrm{ml}$ aniline, $80 \mathrm{ml}$ acetone and $15 \mathrm{ml}$ phosphoric acid (85\%) in $100 \mathrm{ml}$ derivatization reagent) for $3 \mathrm{sec}$ and heating at $120^{\circ} \mathrm{C}$ for 10 min. The sugars were quantified by scanning the HPTLC plates in the scanning densitometer TLC Scanner III (Camag, Berlin/Germany) at $628 \mathrm{~nm}$.

The composition of saccharides, presented as weight percentages of total sugars, was determined from peak areas.

In addition high performance anion exchange chromatography and pulsed amperometric detection (HPAEC-PAD) using a Dionex system (Dionex Corporation, Sunnyvale, CA) were used to analyze some selected samples.

\section{RESULTS}

\section{Immobilization of $\boldsymbol{\beta}$-Galactosidase}

$\beta$-Galactosidase from Kluyveromyces lactis was successfully immobilized on two different anion exchange membranes (Table 2). Average protein capture efficiency, as defined by the amount of protein adsorbed on the membrane divided by the amount of protein in the original solution, was for Mustang ${ }^{\mathrm{TM}} \mathrm{Q}$ between 30 and $36 \%$ depending on the immobilization temperature. Experimental data showed that at immobilization temperature of $40^{\circ} \mathrm{C}$ the lowest enzyme activity was evaluated. This decrease in the activity could be due to the partially denaturizing of enzyme, which was observed during the immobilization procedure in form of white threads in the solution. The highest protein capture efficiency for Mustang ${ }^{\mathrm{TM}} \mathrm{Q}$ was obtained at the immobilization temperature of $4^{\circ} \mathrm{C}$ while the highest enzyme activity in static experiment was measured at 10 and $15^{\circ} \mathrm{C}$ immobilization temperature.

In the static experiments with Sartobind ${ }^{\mathrm{TM}} \mathrm{Q}$ the highest activity of immobilized enzyme was achieved at 10 and $15^{\circ} \mathrm{C}$ immobilization temperature also.
Table 2. Activity of immobilized B-Galactosidase, Static Experiment

\begin{tabular}{|c|c|c|}
\hline \multirow{2}{*}{$\begin{array}{c}\text { Immobilization } \\
\text { Temperature }\end{array}$} & \multicolumn{2}{|c|}{$\begin{array}{c}\text { Activity of Immobilized Enzyme, } 30^{\circ} \mathrm{C} / 0.1 \\
\text { Mol Lactose / } \mathrm{pH} \mathrm{7.0}\end{array}$} \\
\hline & Mustang ${ }^{\mathrm{TM}} \mathbf{Q}$ & Sartobind ${ }^{\mathrm{TM}} Q$ \\
\hline$\left[{ }^{\circ} \mathbf{C}\right]$ & \multicolumn{2}{|c|}{ [NLU/cm $\mathbf{c m}^{3}$ Membrane] } \\
\hline 4 & $193 \pm 40$ & NA \\
\hline 10 & $382 \pm 38$ & $146 \pm 51$ \\
\hline 15 & $346 \pm 46$ & $156 \pm 2$ \\
\hline 40 & $225 \pm 127$ & NA \\
\hline
\end{tabular}

The activity of immobilized enzyme in dynamic experiment (convective flow of substrate through the membrane Fig. (2)) was 3158 (Mustang ${ }^{\mathrm{TM}} \mathrm{Q}$ ) and 850 (Sartobind ${ }^{\mathrm{TM}} \mathrm{Q}$ ) NLU per $\mathrm{cm}^{3}$ membrane volume at $15^{\circ} \mathrm{C}$ immobilization temperature (Table 3). In the case of Sartobind ${ }^{\mathrm{TM}} \mathrm{Q}$, the lower binding capacity of the membrane caused by the different membrane structure and porosity probably results in a lower enzyme activity of the immobilized enzyme.

\section{Reactor Performance}

The results reported below were achieved all with steadystate continuous runs. The feed flow was held equal to the permeate flow (permeate flow rate was 30 or $2.6 \mathrm{ml} / \mathrm{min}$ ).

Table 3. Activity of Immobilized $\beta$-Galactosidase, Dynamic Experiment

\begin{tabular}{|c|c|c|}
\hline \multirow{2}{*}{$\begin{array}{l}\text { Immobilization } \\
\text { Temperature }\end{array}$} & \multicolumn{2}{|c|}{$\begin{array}{l}\text { Activity of Immobilized Enzyme, Residence Time } \\
0.03 \mathrm{~min} / \mathrm{cm}^{3}, 40^{\circ} \mathrm{C} / 0.6 \mathrm{Mol} \text { Lactose } / \mathrm{pH} 7.0\end{array}$} \\
\hline & Mustang $^{\mathrm{TM}} \mathbf{Q}$ & Sartobind ${ }^{\mathrm{TM}} \mathbf{Q}$ \\
\hline$\left[{ }^{\circ} \mathbf{C}\right]$ & \multicolumn{2}{|c|}{ [NLU/cm ${ }^{3}$ Membrane] } \\
\hline 15 & 3158 & 850 \\
\hline
\end{tabular}

Fig. (3) shows representative results with the chromatography membrane Mustang ${ }^{\mathrm{TM}} \mathrm{Q}$ at different processing times in which the processing time was defined as the duration of the continuous synthesis reaction. It is clear that the conversion to oligosaccharides is quite significant. The oligosaccharide yield was nearly constant over the entire processing time which indicates steady-state conditions. Our results showed that a continuous membrane-chromatographyreactor performs well in the production of oligosaccharides from lactose. Two different average residence times were investigated with the chromatography membrane Sartobind ${ }^{\mathrm{TM}} \mathrm{Q}$. Fig. (4) shows average values at equal experimental conditions. The average residence time was defined as:

$\tau=\mathrm{Vr} / \mathrm{v}$

where $\tau$ is the average residence time [min], $\mathrm{Vr}$ the membrane bed volume $\left[\mathrm{m}^{3}\right]$ and $v$ is the permeate flowrate (equal to the feed flowrate) $[\mathrm{ml} / \mathrm{min}]$. The residence time was changed by varying the permeate flow rate. The results showed that the residence time in both experiments had no effect on the yield of oligosaccharides. The increase of 


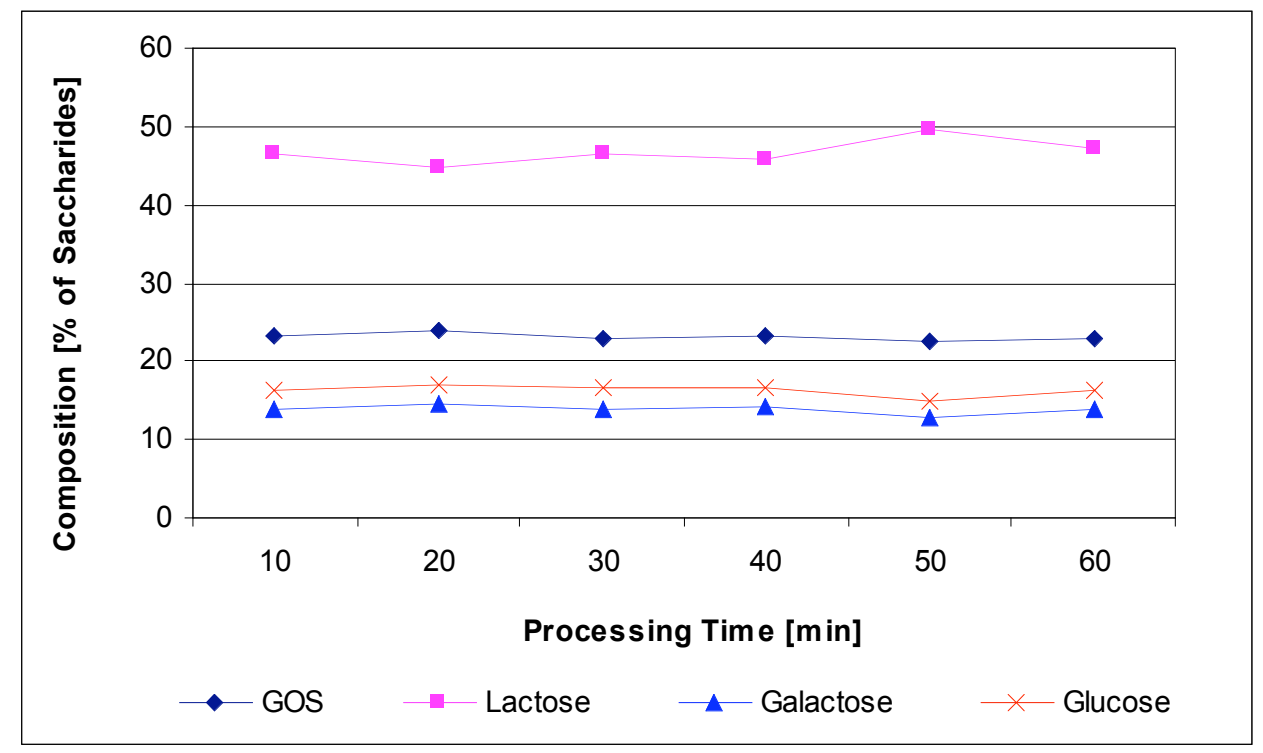

Fig. (3). Production of GOS from lactose in a continuous chromatography-membrane-reactor-system (immobilization temperature: $15^{\circ} \mathrm{C}$, enzyme: Maxilact L 2000, processing temperature: $40^{\circ} \mathrm{C}, \mathrm{pH}: 7.0$, membrane: Mustang ${ }^{\mathrm{TM}} \mathrm{Q}$ (PES), 1 layer, bed volume: $0.878 \mathrm{~cm}^{3}$, lactose concentration: $20 \mathrm{wt} \%)$.

lactose conversion at longer residence time can be explained as residence time controlled lactose hydrolysis. Theoretically, at long residence times the enzyme has more time to react with the substrate. It results in high lactose conversion and in high monosaccharide yield. This behavior can be used well if less lactose concentration in the product is desired.

Fig. (5) shows the comparison between the oligosaccharide production from lactose with the chromatography membrane Sartobind ${ }^{\mathrm{TM}} \mathrm{Q}$ and Mustang ${ }^{\mathrm{TM}} \mathrm{Q}$ at the same conditions. Because of larger pore size and lower binding capacity of Sartobind ${ }^{\mathrm{TM}} \mathrm{Q}$ two Sartobind ${ }^{\mathrm{TM}} \mathrm{Q}$ flat sheet membranes were used in this experiment to achieve the comparable experimental conditions.

The results have demonstrated that the product spectrum and amounts of saccharide fractions were similar for both Sartobind ${ }^{\mathrm{TM}} \mathrm{Q}$ and Mustang ${ }^{\mathrm{TM}} \mathrm{Q}$.

\section{DISCUSSION AND CONCLUSION}

The possibility of using the different chromatography membranes for the immobilization of $\beta$-galactosidase from Kluyveromyces lactis and for synthesis of galactooligosaccharides in a membrane reactor system was shown.

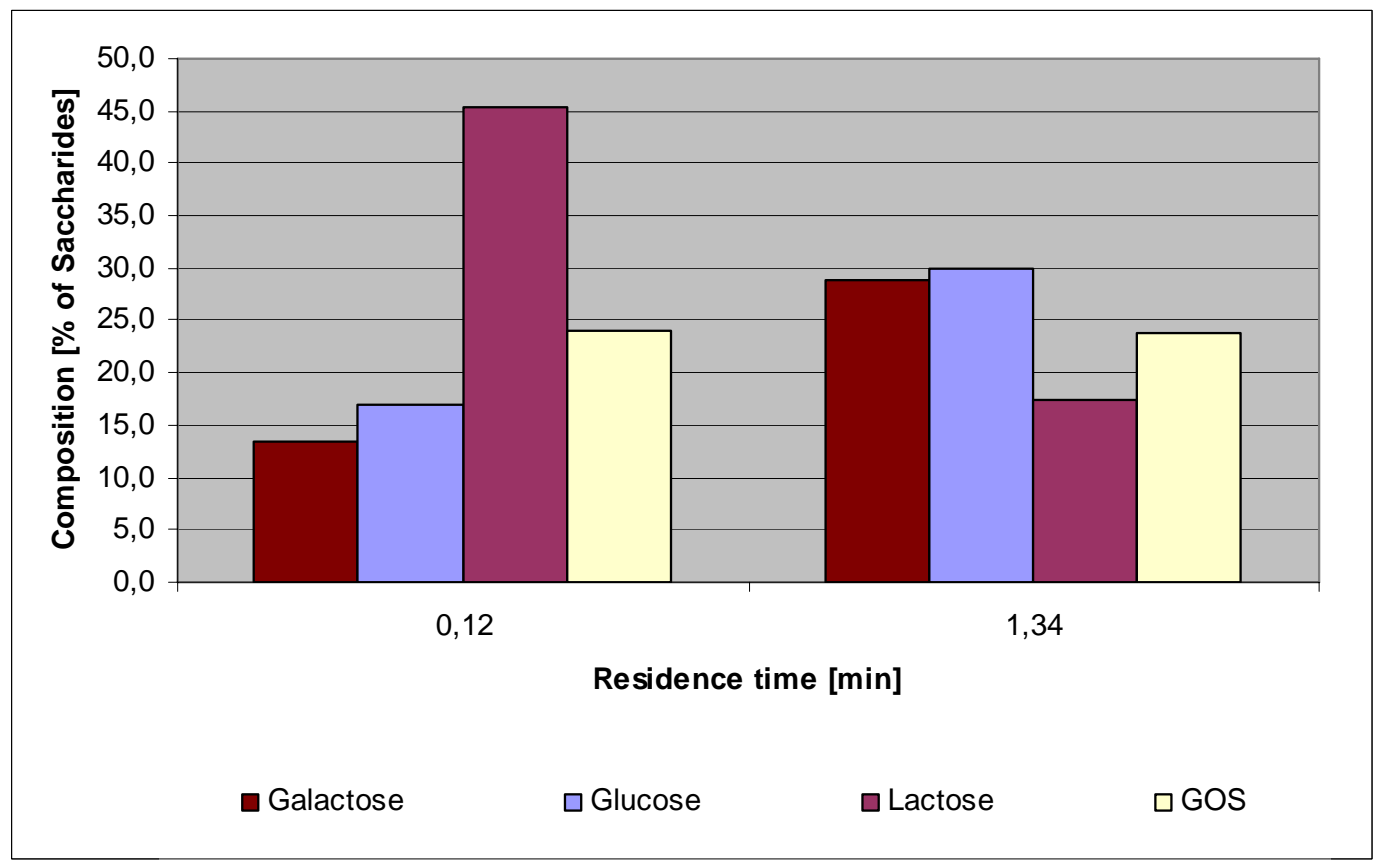

Fig. (4). Production of GOS from lactose in a continuous chromatography-membrane-reactor-system at different residence times (immobilization temperature: $15^{\circ} \mathrm{C}$, enzyme: Maxilact L 2000, processing time: $30 \mathrm{~min}$, processing temperature: $40^{\circ} \mathrm{C}, \mathrm{pH}: 7.0$, membrane: Sartobind ${ }^{\mathrm{TM}} \mathrm{Q}, 2$ layers, bed volume in all: $3.498 \mathrm{~cm}^{3}$, lactose concentration: $20 \mathrm{wt} \%$ ). 


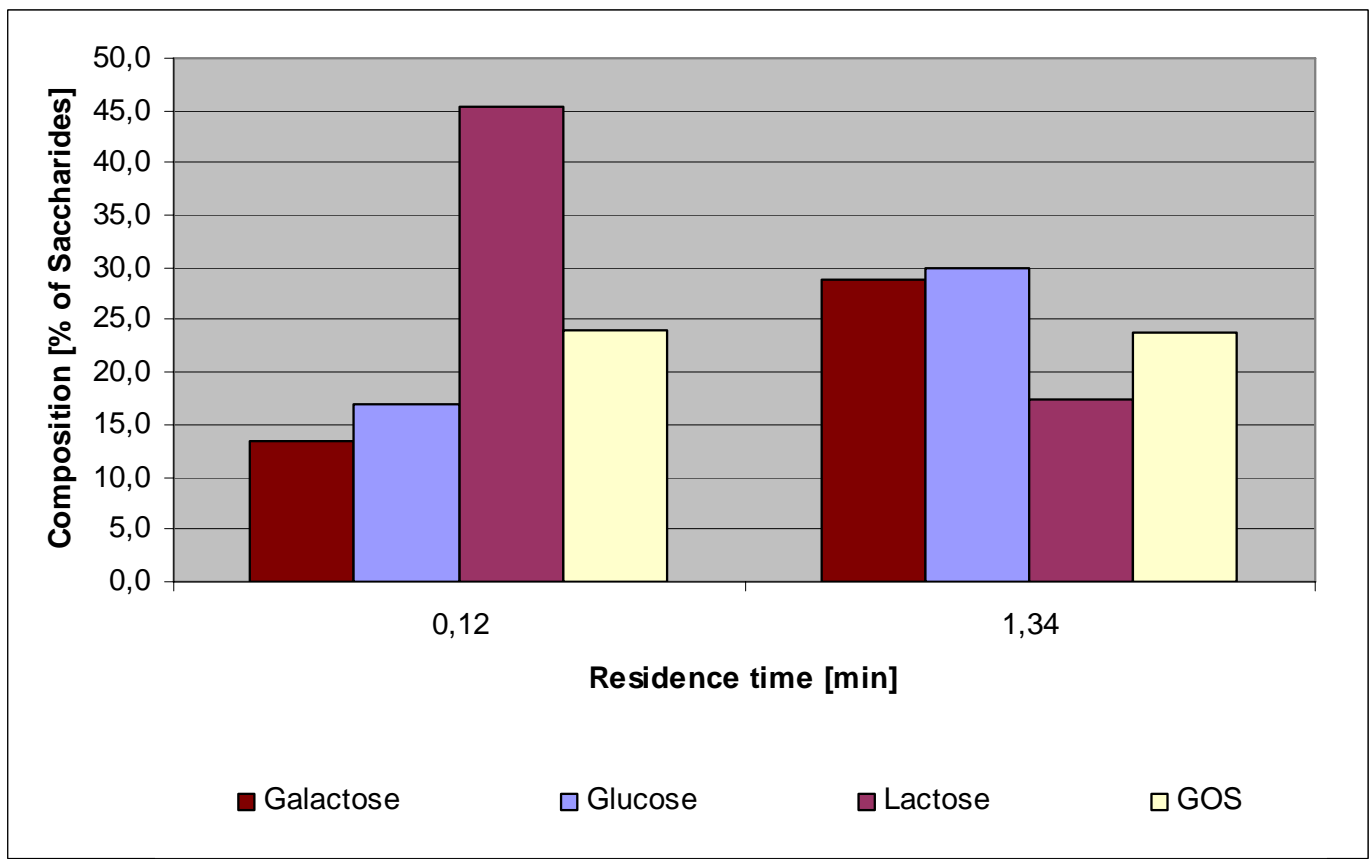

Fig. (5). Production of GOS from lactose in the continuous membrane-chromatography- reactor-system with different membrane properties (specific residence time: $0,03 \mathrm{~min} / \mathrm{cm}^{3}$ membrane volume, membranes: 2 layers Sartobind ${ }^{\mathrm{TM}} \mathrm{Q}, 1$ layer Mustang ${ }^{\mathrm{TM}} \mathrm{Q}$, immobilization temperature: $15^{\circ} \mathrm{C}$, enzyme: Maxilact L 2000, processing time: $30 \mathrm{~min}$, processing temperature: $40^{\circ} \mathrm{C}, \mathrm{pH}: 7.0$, lactose concentration: $20 \mathrm{wt} \%$ ).

In this study, two chromatography membrane types were investigated. Especially, immobilization on Mustang ${ }^{\mathrm{TM}} \mathrm{Q}$ membrane was tested in detail regarding to the effect of temperature on the yield and activity of immobilized enzyme (static experiments).

The results of enzyme immobilization were used as preliminary investigations in order to identify the optimal immobilization conditions for the later synthesis of galactooligosaccharides in a Continuous MembraneChromatography-Reactor-System (CMCRS). It was found that the activity of the immobilized enzyme does not correlate with the protein capture efficiency.

The chromatography membranes proved to be a good support for the continuous process at high convective flow rates in an enzyme reactor.

The lactose conversion varied between $53-82 \%$ in dependence of the flux through the membrane. These results may be proved by further optimization of the process. The immobilization of the enzyme on the chromatography membranes was found to be very rapid because of the strong ionic adsorption.

In dynamic experiments, the enzyme activity on Mustang ${ }^{\mathrm{TM}} \mathrm{Q}$ was measured higher than on Sartobind ${ }^{\mathrm{TM}} \mathrm{Q}$ at similar conditions. The lower enzyme activity on Sartobind ${ }^{\mathrm{TM}} \mathrm{Q}$ can be explained by lower immobilization yield because of the lower binding capacity of the membrane probably caused by different membrane structure and porosity. In addition, the investigations showed that similar fractions of saccharides were produced with both membrane types.

The effect of residence time on the GOS synthesis was shown with Sartobind ${ }^{\mathrm{TM}} \mathrm{Q}$ membranes. Long residence times result in high lactose conversion and high monosaccharide yield. The amount of formed GOS kept constant for the tested residence times.
The corresponding reactor productivity for the production of GOS from lactose with Mustang ${ }^{\mathrm{TM}} \mathrm{Q}$ in a Continuous Membrane-Chromatography-Reactor-System (CMCRS) was 98.7 grams GOS per hour and cubic centimeter membrane volume, which significantly exceeds previously reported. results $[12,13,20]$.

In general the primary comparison to other studies is difficult because different enzyme sources and other basic conditions (buffer, $\mathrm{pH}$, initial lactose concentration, process mode etc.) were used in these studies. For this reason we will describe approximate related studies.

Albayrak and Yang [20] presented a method to immobilize $\beta$-galactosidase from $A$. oryzae on cotton cloth activated with tosyl chloride. In their work, they could realize in a continuous process mode with $200 \mathrm{~g} / \mathrm{L}$ initial lactose concentration a GOS concentration in filtrate of $21.7 \%$ and the reactor productivity of 80 grams GOS per hour and liter reactor volume. In one other study [12] they immobilized the same enzyme on cotton cloth coated with PEI. With this a reactor performance with $400 \mathrm{~g} / \mathrm{L}$ initial lactose concentration a GOS concentration of maximal $24 \%$ in filtrate was attained and the reactor productivity about 106 grams GOS per hour and liter reactor volume in continuous process mode.

Foda and Lopez-Leiva [13] used hollow fiber membranes and free $\beta$-galactosidase from Kluyveromyces lactis to produce GOS in a continuous system. The enzyme was given in excess to whey containing $200 \mathrm{~g} / \mathrm{L}$ initial lactose. The GOS concentration in final product was $6.2 \%$ and the reactor productivity 3.1 grams GOS per hour and liter membrane reactor volume.

\section{REFERENCES}

[1] Mahoney RR. Galactosyl-oligosaccharide formation during lactose hydrolysis: a review. Food Chem 1998; 63: 147-154. 
[2] Gekas V, Lopez-Leiva M. Hydrolysis of lactose: a literature review. Proc Biochem 1985; 20: 2-12.

[3] Prenosil JE, Stuker E, Borne JR. Formation of oligosaccharides during enzymatic lactose hydrolysis and their importance in a whey hydrolysis process: Part II: experimental. Biotechnol Bioeng 1987; 30: 1026-1031.

[4] Sako T, Matsumoto K, Tanak R. Recent progress on research and applications of nondigestible galacto-oligosaccharides. Int Dairy J 1999; 9: 69-80.

[5] Fooks LJ, Fuller R, Gibson GR. Prebiotics, probiotics and human gut microbiology. Int Dairy J 1999; 9: 53-61.

[6] Oku T. Oligosaccharides with beneficial effects: A Japanese perspective. Nutr Rev 1996; 54: 59-66.

[7] Gibson G, Roberfroid MB. Dietary modulation of the human colonic microbiology: introducing the concept of prebiotics. J Nutr 1998; 80(Suppl 1): 147-171.

[8] Boon MA, Janssen AEM, van't Riet K. Effect of temperature and enzyme origin on the enzymatic synthesis of oligosaccharides. Enzyme Microbial Technol 2000; 26: 271-281.

[9] Nakanishi K, Matsuno R, Kasuyuki T, et al. Properties of immobilized $\beta$-galactosidase from B. circulans. Enzyme Microb Technol 1983; 5: 115-120.

[10] Gaur R, Pant H, Jain R, Khare SK. Galacto-oligosaccharide synthesis by immobilized Aspergillus oryzae $\beta$-galactosidase. Food Chem 2006; 97: 426-430.

[11] Wentworth DS, Skonberg D, Donahue DW. Application of chitosan-entrapped $\beta$-galactosidase in a packed-bed reactor system. J Appl Polymer Sci 2004; 91: 1294-1299.
[12] Albayrak N, Yang ST. Immobilization of $\beta$-galactosidase on fibrous matrix by polyethyleneimine for production of galactooligosaccharides from lactose. Biotechnol Prog 2002; 18: 240-251.

[13] Foda MI, Lopez-Leiva M. Continuous production of oligosaccharides from whey using a membrane reactor. Proc Biochem 2000; 35: 581-587.

[14] Czermak P, Ebrahimi M, Grau K, Netz S, et al. Membrane-assisted enzymatic production of galactosyl-oligosaccharides from lactose in a continuous process. J Membr Sci 2004; 232: 85-91.

[15] Hernaiz MJ, Crout DHG. Immobilization/stabilization on Eupergit $\mathrm{C}$ of the $\beta$-galactosidase from B. circulans and an $\alpha$-galactosidase from Aspergillus oryzae. Enzyme Microbial Technol 2000; 27: 2632.

[16] Cheethan PSJ. Principles of industrial enzymology: Basis of utilization of soluble and immobilized enzymes in industrial processes. In Weisman, A. (Ed.), Handbook of enzyme technology, John Wiley, New York 1985, pp. 54-146.

[17] Gottschalk U, Fischer-Fruehholz S, Reif O. Membrane adsorbers: a cutting edge process technology at the threshold. Bioproc Inter 2004; 56-65.

[18] Carpio C, Gonzalez P, Ruales J, Batista-Viera F. Bone-bound enzymes for food industry application. Food Chem 2000; 68: 403409.

[19] Ghosh R. Review. Protein separation using membrane chromatography: opportunities and challenges. J Chrom A 2002; 952: 13-27.

[20] Albayrak N, Yang ST. Production of galacto-oligosaccharides from lactose by Aspergillus oryzae $\beta$-galactosidase immobilized on cotton cloth. Biotechnol Bioeng 2002; 77: 8-19. 